\title{
THE EFFECT OF PRINCIPAL'S MANAGERIAL ABILITY AND WORK DISCIPLINE ON TEACHERS' PERFORMANCE IN PUBLIC ELEMENTARY SCHOOLS IN KECAMATAN TAMBAKROMO, KABUPATEN PATI
}

\author{
Wiwik Subekti ${ }^{1}$, Suad $^{2}$, Gunawan Setiadi ${ }^{3}$ \\ ${ }^{1,2}$ Universitas Muria Kudus, Kudus, Indonesia \\ I'wiwik.karmain@gmail.com, ${ }^{2}$ suad@umk.ac.id, ${ }^{3}$ gunsetia@gmail.com
}

\begin{abstract}
The purpose of this study was to analyze the effect of the Principal's managerial ability on teachers' performance, the effect of work discipline on teachers ' performance, and the influence of Principal's managerial ability and work discipline in multiple ways on teachers 'performance. This research was conducted at SD Negeri in Kecamatan Tambakromo, Kabupaten Pati. The type of this study was quantitative research through survey methods to elementary school teachers in Kecamatan Tambakromo, Kabupaten Pati. The samples in this study were 191 respondents, which was selected through incidental techniques. The data collection technique was by giving a questionnaire to the teachers. The data analysis test used validity, reliability, classic assumption tests and multiple linear tests which were processed by using IBM SPSS 24. The results showed the following: (1) Principal's managerial ability $\left(X_{l}\right)$ was proven to have a significant effect on teachers' performance in SD Negeri in Kecamatan Tambakromo, Kabupaten Pati. The $t$-test result showed that the sig value. Was equal to $0.000<0.05$ and $t_{\text {count }} 6.520>t_{\text {table }} 1.9727$. (2) Work discipline $\left(X_{2}\right)$ was proven to have a significant effect on teachers' performance in SD Negeri in Kecamatan Tambakromo, Kabupaten Pati. The t-test result showed that the sig value was equal to $0.000<0.05$ and the value of $t_{\text {count }} 7.206>t_{\text {table }} 1.9727$. (3) Principal's managerial ability and work discipline simultaneously proved to have a significant effect on teachers' performance in SD Negeri in Kecamatan Tambakromo, Kabupaten Pati. The results of the F-test showed that the sig. was equal to $0.000<0.05$ and the value of $f_{\text {count }} 229.714>f_{\text {tabel }} 3.04$ and simultaneously influenced the teachers' performance variable ( $Y$ ) of $71 \%$.
\end{abstract}

Keywords: principal managerial ability, work discipline and teacher performance

\section{PENGARUH KEMAMPUAN MANAJERIAL KEPALA SEKOLAH DAN DISIPLIN KERJA TERHADAP KINERJA GURU SEKOLAH DASAR NEGERI DI KECAMATAN TAMBAKROMO KABUPATEN PATI}

\begin{abstract}
ABSTRAK
Tujuan penelitian ini untuk menganalisis pengaruh kemampuan manajerial kepala sekolah terhadap kinerja guru. Menganalisis pengaruh disiplin kerja terhadap kinerja guru. Dan menganalisis pengaruh kemampuan manajerial kepala sekolah dan disiplin kerja disiplin kerja secara berganda terhadap kinerja guru. Penelitian ini dilaksanakan di Sekolah Dasar Negeri di Kecamatan Tambakromo Kabupaten Pati. Jenis penelitian yang digunakan adalah penelitian kuantitatif melalui metode survey kepada guru Sekolah Dasar Negeri di Kecamatan Tambakromo Kabupaten Pati. Jumlah sampel dalam penelitian ini sebanyak 191 responden, penentuan sampel menggunakan teknik insindental. Teknik pengumpulan data dengan memberi kuesioner pada guru. Pengujian analisis data menggunakan uji validitas, realibilitas, uji asumsi klasik dan uji linier berganda yang diolah menggunakan IBM SPSS 24. Hasil penelitian menunjukkan sebagai berikut: (1) Kemampuan managerial kepala sekolah terbukti memiliki pengaruh signifikan terhadap kinerja guru di SD Negeri Kecamatan Tambakromo Kabupaten Pati. Hasil uji t menunjukkan nilai sig. sebesar 0,000 < 0,05 dan nilai $t_{\text {hitung }} 6,520>t_{\text {tabel }}$ 1,9727. (2) Disiplin kerja terbukti memiliki pengaruh signifikan terhadap kinerja guru di SD Negeri Kecamatan Tambakromo Kabupaten Pati. Hasil uji t menunjukkan nilai sig. sebesar 0,000 < 0,05 dan nilai thitung 7,206 > tabel 1,9727 . (3) Kemampuan managerial kepala sekolah dan disiplin kerja secara simultan terbukti memiliki pengaruh signifikan terhadap kinerja guru di SD Negeri Kecamatan Tambakromo Kabupaten Pati. Hasil uji Ft menunjukkan nilai sig. sebesar 0,000 <0,05 dan nilai $f_{\text {hitung }} 229,714>f_{\text {tabel }}$ 3,04 dan berpengaruh secara simultan terhadap variabel kinerja guru $(Y)$ sebesar $71 \%$.
\end{abstract}

Kata Kunci: kemampuan manajerial kepala sekolah, disiplin kerja, dan kinerja guru

\begin{tabular}{|c|c|c|}
\hline Submitted & Accepted & Published \\
\hline 23 Agustus 2020 & 05 September 2021 & 16 September 2021 \\
\hline
\end{tabular}

\begin{tabular}{|l|l|c|}
\hline Citation & $:$ & $\begin{array}{r}\text { Subekti, W., Suad, S., \& Setiadi, G. (2021).The Effect of Principal's Managerial Ability and Work Discipline on Teachers' } \\
\text { Performance in Public Elementary Schools in Kecamatan Tambakromo, Kabupaten Pati. Jurnal PAJAR } \\
\text { (Pendidikan dan Pengajaran), 5(5), 1360-1368. DOI : http://dx.doi.org/10.33578/pjr.v5i5.8123. }\end{array}$ \\
\hline
\end{tabular}




\section{PENDAHULUAN}

Pembukaan Undang-Undang Dasar Negara Republik Indonesia Tahun 1945 menyatakan bahwa tujuan pendidikan nasional adalah untuk melindungi segenap bangsa dan seluruh tumpah darah Indonesia dan untuk memajukan kesejahteraan umum, mencerdaskan kehidupan bangsa, dan ikut melaksanakan ketertiban dunia berdasarkan kemerdekaan, perdamaian abadi, dan keadilan sosial. Perhatian pemerintah terhadap dunia pendidikan beberapa tahun terakhir semakin meningkat, dilihat pemberlakuan sekolah gratis dan peningkatan anggaran negara untuk biaya pendidikan, penerapan standar kelulusan melalui UAN, penerapan kurikulum 2013, dan lain-lain.

Kinerja guru sebagai seperangkat perilaku nyata yang ditunjukkan guru pada waktu dia memberikan pembelajaran kepada siswa. Menurut Undang- Undang RI nomor 14 tahun 2005 tentang Guru dan Dosen, pada bab 1 pasal 1 disebutkan bahwa : "Guru adalah pendidik professional dengan tugas utama mendidik, mengajar, membimbing, mengarahkan, melatih, menilai dan mengevaluasi peserta didik pada pendidikan usia dini jalur pendidikan formal, pendidikan dasar, dan pendidikan menengah". Guru diharapkan memiliki kinerja yang baik dalam melaksanakan tugasnya di sekolah untuk meningkatkan mutu pendidikan, baik secara individu maupun kelompok. Kinerja guru adalah kemampuan dan usaha guru untuk melaksanakan tugas pembelajaran sebaik-baiknya dalam perencanaan program pengajaran, pelaksanaan kegiatan pembelajaran dan evaluasi hasil pembelajaran (Suherman dan Ondi, 2010:23).

Kepala sekolah sebagai pelaksana bertanggungjawab atas penyelenggaraan kegiatan pendidikan, administrasi sekolah, pembinaan tenaga kependidikan lainnya dan pendayagunaan serta pemeliharaan (Susanto, 2016: 29). Mengacu pada Pasal 15 Permendikbud Nomor 6 Tahun 2018 Tentang Penugasan Guru Sebagai Kepala Sekolah, dinyatakan jika tugas pokok dan fungsi kepala sekolah ialah sebagai berikut :

1. Beban kerja Kepala Sekolah seluruhnya untuk melaksanakan tugas pokok manajerial, pengembangan kewirausahaan, dan supervisi kepada Guru dan tenaga kependidikan.

2. Beban kerja Kepala Sekolah bertujuan untuk mengembangkan sekolah dan meningkatkan mutu sekolah berdasarkan 8 (delapan) standar nasional pendidikan .

3. Saat terjadi kekurangan guru dalam satuan pendidikan tertentu, maka Kepala Sekolah bisa melaksanakan tugas pembelajaran maupun pembimbingan agar proses pembelajaran maupun pembimbingan tetap berlangsung dalam satuan pendidikan yang bersangkutan tersebut.

4. Kepala Sekolah yang melaksanakan tugas pembelajaran atau pembimbingan, tugas pembelajaran atau pembimbingan tersebut merupakan tugas tambahan di luar tugas pokoknya .

5. Beban kerja bagi kepala sekolah yang ditempatkan di SILN selain melaksanakan beban kerja juga melaksanakan promosi kebudayaan Indonesia.

Bidang manajerial ini berhubungan dengan pengelolaan sekolah, sehingga seluruh sumber daya bisa disediakan dan dimanfaatkan secara optimal demi mencapai tujuan sekolah secara efektif serta efisien. Kemampuan manajerial adalah pengetahuan, keterampilan, dan pengalaman yang tidak berwujud yang dapat dimanfaatkan oleh pimpinan (Sofyan, 2012:88). Kemampuan manajerial kepala sekolah dalam kapasitasnya sebagai pemimpin sangat penting bagi keberhasilan dalam meningkatkan kinerja guru di bawah kepemimpinannya. Fenomena yang terjadi di sekolah dasar negeri se Kecamatan Tambakromo saat ini permasalahan yang terjadi di antaranya, 1) kepala sekolah kesulitan dalam menghimpun pendapat-pendapat dari guru maupun karyawan untuk membuat keputusan dalam suatu perencanaan karena minimnya budaya inisiatif untuk memberikan pendapatan. 2) kesulitan yang dihadapi kepala sekolah selanjutnya adalah kebiasaan-kebiasaan, kemauan dan keterampilan guru yang belum sesuai dengan program yang dijalankan kepala sekolah. 3) kurang optimalnya fokus pengawasan kepala 
sekolah terhadap pelaksanaan program sekolah. Kepala sekolah menjadi ujung tombak dari sebuah lembaga sekolah, dan sebagai kepala sekolah juga dituntut untuk meningkatkan kinerja guru salah satunya dengan kemampuan managerial yang dimiliki kepala dalam menjalankan tugasnya sebagai pemimpin di sekolah, karena dengan meningkatnya kinerja guru akan membawa dampak positif bagi sekolah yang dipimpinnya. Hal ini sejalan dengan penelitian yang dilakukan oleh Amanda dan Yoyon (2018) yang menyatakan bahwa terdapat hubungan yang signifikan antara kemampuan manajerial dengan kinerja guru, semakin tinggi kemampuan manajerial kepala sekolah maka semakin tinggi pula kinerja guru.

Berbagai aturan atau norma yang ditetapkan oleh suatu lembaga pendidikan memiliki peran yang sangat penting dalam menciptakan kedisiplinan agar para guru atau tenaga kependidikan dapat mematuhi peraturan tersebut. Disiplin merupakan kewajiban yang harus ditaati dan larangan yang tidak boleh dilanggar oleh setiap pegawai/guru (Moenir, 2012:94). Unsur-unsur yang melekat pada kedisiplinan seorang guru disekolah diantaranya: 1) Kehadiran, merupakan tingkat absensi karyawan/guru sesuai waktu yang sudah ditetapkan, 2) Waktu kerja, yaitu waktu untuk melakukan pekerjaan, 3) Produktivitas kerja, merupakan perbandingan hasil yang lebih baik dari sebelumnya, 4) Pemakaian seragam, satu set pakaian standard yang dikenakan oleh ahli suatu organisasi sewaktu menyertai dalam aktivitas organisasi tersebut. Nitisemito (2014:199) mengatakan bahwa masalah kedisiplinan kerja guru merupakan masalah yang perlu diperhatikan, sebab dengan adanya kedisiplinan, dapat mempengaruhi efektivitas dan efisiensi pencapaian tujuan organisasi. Hal itu dimaksudkan agar para guru atau tenaga kependidikan bekerja dengan disiplin dan bertanggungjawab atas pekerjaannya. Fenomena yang terjadi di sekolah dasar negeri se kecamatan Tambakromo saat ini masih ada beberapa guru yang terlambat datang ke sekolah. Hal itu menyebabkan waktu pembelajaran semakin berkurang, masih terdapat pula beberapa guru yang belum membuat persiapan pembelajaran sebelum mengajar, padahal diketahui bahwa persiapan pembelajaran sangat berpengaruh terhadap kelancaran pembelajaran. Hal tersebut tentunya sangat mempengaruhi kinerja guru kaitannya kedisiplinan seorang guru dalam melaksanakan kewajibannya sebagai pendidik. Hal ini sejalan dengan Nugraheni, dkk (2016) yang menyatakan bahwa disiplin kerja sangat berpengaruh positif dan signifikan terhadap kinerja guru.

Guru sebagai pendidik tentunya mempunyai kewajiban untuk meningkatkan kinerjanya. Kinerja yang baik dapat diraih guru apabila melaksanakan pekerjaan dan tugastugasnya dengan baik. Hal ini bisa di lihat dari tugas dan tanggung jawab guru menurut (Mulyasa, 2013:75) yaitu: 1) Dalam proses belajar mengajar guru sudah mengikuti standar pendidikan yang saat ini digunakan yaitu menggunakan KTSP dan Kurikulum 2013, 2) Guru sudah disiplin dalam menjalankan tugasnya sebagai pendidik, 3) Guru sudah memberikan motivasi kepada para siswa untuk lebih giat belajar. 4) Guru juga menggunakan strategi pembelajaran, penggunaan media dan sumber belajar, dan 5) Guru sudah menyusun administrasi secara tertib. Untuk itu, dari beberapa fenomena yang muncul pada guru sekolah dasar negeri se Kecamatan Tambakromo perlu adanya upaya peningkatan kinerja guru salah satunya adalah dengan meningkatkan tingkat kedisiplinan kerja guru agar guru bersemangat dalam menyeleaikan tanggung jawabnya sebagai pendidik. Selain faktor disiplin kerja yang diberikan oleh guru, kemampuan manajerial seorang pemimpin juga dapat berpengaruh terhadap peningkatkan kinerja guru. Hal ini sejalan dengan penelitian yang dilakukan oleh Gita, dkk (2018) yang menyatakan bahwa terdapat pengaruh yang signifikan kemampuan manajerial Kepala Sekolah, disiplin kerja secara stimultan terhadap kinerja guru.

Berdasarkan fenomena dan gap riset, tujuan yang ingin dicapai dari penelitian ini adalah untuk :

1. Menganalisis pengaruh kemampuan manajerial kepala sekolah terhadap kinerja guru di Sekolah Dasar Negeri di Kecamatan Tambakromo Kabupaten Pati. 
2. Menganalisis pengaruh disiplin kerja terhadap kinerja guru di Sekolah Dasar Negeri di Kecamatan Tambakromo Kabupaten Pati.

3. Menganalisis pengaruh kemampuan manajerial kepala sekolah dan disiplin kerja secara berganda terhadap kinerja guru di Sekolah Dasar Negeri di Kecamatan Tambakromo Kabupaten Pati.

\section{KAJIAN TEORETIS}

\section{Kemampuan Kemampuan Manajerial} Kepala Sekolah

Kemampuan manajerial adalah pengetahuan, keterampilan, dan pengalaman yang tidak berwujud yang dapat dimanfaatkan oleh pimpinan (Sofyan, 2012:88). Sedangkan Damayanti (2017:157) menyatakan bahwa kemampuan manajerial kepala sekolah adalah kemampuan untuk melakukan aktifitas manajemen yang dilakukan kepala sekolah secara prosedural untuk memberdayakan semua sumber daya yang tersedia untuk mencapai tujuan organisasi secara efektif dan efisien. Dapat disimpulkan bahwa kemampuan manajerial adalah kemampuan seseorang dalam memimpin, mengorganisasikan, merencanakan dan mengendalikan sesuai dengan prosedural dalam mencapai tujuan.

Tugas dan fungsi dibidang manajerial kepala sekolah dalam Permendiknas Nomor 28 Tahun 2010 tentang Penugasan Guru sebagai Kepala Sekolah/Madrasah, meliputi aktivitas Menyusun perencanaan sekolah, Mengelola program pembelajaran, Mengelola kesiswaan, Mengelola sarana dan prasarana, Mengelola personal sekolah, Mengelola keuangan sekolah, Mengelola hubungan sekolah dan masyarakat, Mengelola administrasi sekolah, Mengelola sistem informasi sekolah, Mengevaluasi program sekolah, Memimpin sekolah.

\section{Disiplin Kerja}

Menurut PP Republik Indonesia no 53 tahun 2010 tentang disiplin pegawai negeri sipil pasal 1 menyebutkan bahwa disiplin pegawai negeri sipil adalah kesanggupan pegawai negeri sipil untuk menaati kewajiban dan menghindari larangan yang ditentukan dalam peraturan perundang-undangan dan/atau peraturan kedinasan yang apabila tidak ditaati atau dilanggar dijatuhi hukuman disiplin. Sedangkan Rivai (2011:123) menyatakan bahwa disiplin kerja adalah suatu alat yang digunakan para manajer untuk berkomunikasi dengan karyawan agar mereka bersedia untuk mengubah suatu perilaku sebagai suatu upaya untuk meningkatkan kesadaran dan kesediaan seseorang mematuhi semua peraturan perusahaan dan norma-norma sosial yang berlaku. Dapat disimpulkan bahwa disiplin kerja merupakan kesanggupan pegawai untuk menaati kewajiban dan menghindari larangan yang ditentukan dalam peraturan perundang-undangan dan/atau peraturan kedinasan yang apabila tidak ditaati atau dilanggar akan dijatuhi hukuman disiplin.

Indikator disiplin kerja yang dikembangkan oleh Soedjono dalam Pratama (2014:6), mengemukakan bahwa indikator disiplin kerja pegawai: 1) Ketepatan waktu, 2) Menggunakan peralatan kantor dengan baik, 3) Tanggung jawab yang tinggi,dan 4) Ketaatan terhadap aturan kantor.

\section{Kinerja Guru}

Kinerja guru merupakan keahlian dan keberhasilan guru dalam melaksanakan tugastugas pembelajaran di sekolah (Supardi, 2014: 23). Sedangkan Uno dan Lamatenggo (2014: 86) kinerja guru adalah hasil kerja guru yang terefleksi dalam cara merencanakan, melaksanakan dan menilai proses belajar mengajar yang intensitasnya dilandasi oleh etos kerja, serta disiplin profesional dalam proses pembelajaran. Suherman dan Saondi (2010:23) yang menyatakan bahwa kinerja guru adalah kemampuan dan usaha guru untuk melaksanakan tugas pembelajaran sebaik-baiknya dalam perencanaan program pengajaran, pelaksanaan kegiatan pembelajaran dan evaluasi hasil pembelajaran. Sedangkan Hadis (2010:9), kinerja guru adalah kemampuan seorang guru dalam melaksanakan proses pembelajaran di kelas sesuai dengan tujuan yang telah ditetapkan.

Dapat disimpulkan bahwa kinerja guru adalah kemampuan dan usaha guru untuk melaksanakan tugas pembelajaran sebaik-baiknya dalam perencanaan program pengajaran, pelaksanaan kegiatan pembelajaran dan evaluasi hasil pembelajaran. Indikator kinerja guru yang dikembangkan oleh Mangkunegara (2013:67) : 1) 
Kualitas Kerja, 2) Kuantitas, 3) Tanggung Jawab, dan 4) Kerjasama.

\section{METODE PENELITIAN}

Penelitian ini menggunakan pendekatan penelitian kuantitatif. Teknik pengumpulan data yang digunakan adalah angket (questionnaire) berjenis angket tertutup dengan instrumennya berupa pertanyaan-pertanyaan yang diberikan kepada responden. Penelitian ditujukan kepada guru ASN dan Non ASN yang dilakukan di Sekolah Dasar di Negeri Kecamatan Tambakromo dengan jumlah 191 tenaga pendidik sebagai sampel penelitian.

\section{HASIL DAN PEMBAHASAN}

Responden pada penelitian ini sebanyak 122 guru (63.9\%) dengan status kepegawaian ASN, dan sisanya yaitu sebanyak 69 guru (36.1\%) dengan status kepegawaian Non ASN. Dan sebanyak 51 guru (26.7\%) dengan jenis kelamin laki-laki, dan sisanya yaitu sebanyak 140 guru (73.3\%) dengan jenis kelamin perempuan.

Hasil uji regresi pada penelitian ini diperoleh sebagai berikut pada tabel 1 .

Tabel 1. Hasi Uji Regresi Linier

\begin{tabular}{|c|c|c|c|c|c|c|}
\hline \multicolumn{7}{|c|}{ Coefficients $^{\mathrm{a}}$} \\
\hline & \multirow[t]{2}{*}{ Model } & \multicolumn{2}{|c|}{$\begin{array}{l}\text { Unstandardized } \\
\text { Coefficients }\end{array}$} & \multirow{2}{*}{$\begin{array}{c}\begin{array}{c}\text { Standardized } \\
\text { Coefficients }\end{array} \\
\text { Beta }\end{array}$} & \multirow{2}{*}{$\mathrm{t}$} & \multirow{2}{*}{ Sig. } \\
\hline & & $\mathrm{B}$ & $\begin{array}{l}\text { Std. } \\
\text { Error }\end{array}$ & & & \\
\hline \multirow{3}{*}{1} & (Constant) & 1.476 & 1.901 & & 0.777 & 0.438 \\
\hline & $\begin{array}{l}\text { Kemampuan } \\
\text { Managerial }\end{array}$ & 0.222 & 0.034 & 0.422 & 6.520 & 0.000 \\
\hline & Disiplin Kerja & 0.397 & 0.055 & 0.467 & 7.206 & 0.000 \\
\hline
\end{tabular}

Hasil perhitungan regresi dihitung dengan rumus persamaan $\mathrm{Y}=\mathrm{a}+\mathrm{b}_{1} \mathrm{X}_{1}+\mathrm{b}_{2} \mathrm{X}_{2}$ $=1.476+0.222 . \mathrm{X}_{1}+0.397 . \mathrm{X}_{2}$

Hasil uji regresi linier didapat nilai konstanta (a) sebesar 1.476, artinya tanpa pengaruh dari ketiga variabel independen, maka variabel kinerja guru $(\mathrm{Y})$ mempunyai nilai sebesar 1.476. Koofisien regresi kemampuan manajerial kepala sekolah sebesar 0.222 menyatakan bahwa setiap terjadi kenaikan kemampuan manajerial kepala sekolah satu satuan akan meningkatkan kinerja guru sebesar 0.222 tanpa dipengaruhi variabel lain. Koofisien regresi disiplin kerja sebesar 0.397 menyatakan bahwa setiap terjadi kenaikan disiplin kerja satu satuan akan meningkatkan kinerja guru sebesar 0.397 tanpa dipengaruhi variabel lain dengan rumus $\mathrm{t}_{\text {tabel }}=(\mathrm{a} / 2 ; \mathrm{n}-\mathrm{k}-1)=(0,05 / 2 ; 191-3-1)=$ $0.025 ; 187=1.9727$

Pengujian Hipotesis Pertama, nilai Sig. untuk pengaruh $\mathrm{X}_{1}$ terhadap $\mathrm{Y}$ adalah sebesar $0.000<0.05$ dan nilai $\mathrm{t}_{\text {hitung }} 6.520>\mathrm{t}_{\text {tabel }}$ 1.9727, sehingga dapat disimpulkan bahwa $\mathrm{H}_{1}$ diterima yang berarti terdapat pengaruh kemampuan manajerial kepala sekolah $\left(\mathrm{X}_{1}\right)$ terhadap kinerja guru (Y). Pengujian Hipotesis Kedua, nilai Sig. untuk pengaruh $\mathrm{X}_{2}$ terhadap $\mathrm{Y}$ adalah sebesar $0.000<0.05$ dan nilai $\mathrm{t}_{\text {hitung }} 7.206>\mathrm{t}_{\text {tabel }}$ 1.9727, sehingga dapat disimpulkan bahwa $\mathrm{H}_{2}$ diterima yang berarti terdapat pengaruh disiplin kerja $\left(\mathrm{X}_{2}\right)$ terhadap kinerja guru $(\mathrm{Y})$.

Uji $\mathrm{F}$ digunakan untuk mengetahui tingkat siginifikansi pengaruh variabel-variabel independen secara bersama-sama (simultan) terhadap variabel dependen (Ghozali, 2016:99). Hasil uji $\mathrm{F}$ dapat dilihat pada tabel 2. 
Tabel 2. Hasi Uji F

\begin{tabular}{|c|c|c|c|c|c|c|}
\hline \multicolumn{7}{|c|}{ ANOVA $^{a}$} \\
\hline & Model & $\begin{array}{l}\text { Sum of } \\
\text { Squares }\end{array}$ & $\mathrm{df}$ & $\begin{array}{l}\text { Mean } \\
\text { Square }\end{array}$ & $\mathrm{F}$ & Sig. \\
\hline \multirow{3}{*}{1} & Regression & 2547.954 & 2 & 1273.977 & 229.714 & $.000^{\mathrm{b}}$ \\
\hline & Residual & 1042.633 & 188 & 5.546 & & \\
\hline & Total & 3590.586 & 190 & & & \\
\hline \multicolumn{7}{|c|}{ a. Dependent Variable: Kinerja Guru } \\
\hline \multicolumn{7}{|c|}{ b. Predictors: (Constant), Disiplin Kerja, Kemampuan Managerial } \\
\hline
\end{tabular}

Diperoleh $\mathrm{F}_{\text {tabel }}$ dengan rumus $\mathrm{F}_{\text {tabel }} \quad=(\mathrm{k} ; \mathrm{n}-$ $\mathrm{k})=(2 ; 191-2)=(2 ; 189)=3.04$

Diketahui nilai Sig. untuk pengaruh kemampuan manajerial kepala sekolah $\left(\mathrm{X}_{1}\right)$ dan disiplin kerja $\left(\mathrm{X}_{2}\right)$ terhadap kinerja guru $(\mathrm{Y})$ adalah sebesar $0.000<0.05$ dan nilai $\mathrm{f}_{\text {hitung }} 229.714>\mathrm{f}_{\text {tabel }}$
3.04, sehingga dapat disimpulkan bahwa $\mathrm{H}_{3}$ diterima yang berarti kemampuan manajerial kepala sekolah $\left(\mathrm{X}_{1}\right)$ dan disiplin kerja $\left(\mathrm{X}_{2}\right)$ terdapat pengaruh secara simultan terhadap kinerja guru (Y). Hasil uji koofisien determinasi dapat dilihat pada tabel 3 .

Tabel 3. Koefisien Determinasi $\left(\mathbf{R}^{2}\right)$

\begin{tabular}{|c|c|c|c|c|c|}
\hline \multicolumn{6}{|c|}{ Model Summary ${ }^{b}$} \\
\hline Model & $\mathrm{R}$ & $\begin{array}{c}\mathrm{R} \\
\text { Square }\end{array}$ & $\begin{array}{c}\text { Adjusted } \\
\text { R } \\
\text { Square }\end{array}$ & $\begin{array}{l}\text { Std. Error } \\
\text { of the } \\
\text { Estimate }\end{array}$ & $\begin{array}{l}\text { Durbin- } \\
\text { Watson }\end{array}$ \\
\hline 1 & $.842^{\mathrm{a}}$ & 0.710 & 0.707 & 2.355 & 1.788 \\
\hline \multicolumn{5}{|c|}{ a. Predictors: (Constant), Disiplin Kerja, Kemampuan Managerial } & \\
\hline
\end{tabular}

Berdasarkan output di atas diketahui nilai $\mathrm{R}$ Square sebesar 0.71, hasil penelitian membuktikan bahwa pengaruh variabel kemampuan manajerial kepala sekolah $\left(\mathrm{X}_{1}\right)$ dan disiplin kerja $\left(\mathrm{X}_{2}\right)$ secara simultan terhadap variabel kinerja guru (Y) adalah sebesar $71 \%$.

\section{Pengaruh Kemampuan Manajerial Kepala Sekolah terhadap Kinerja Guru}

Hasil penelitian menunjukkan bahwa kemampuan manajerial kepala sekolah berpengaruh signifikan terhadap kinerja guru di SD Negeri Kecamatan di Tambakromo Kabupaten Pati. Hasil tanggapan responden terhadap variabel kemampuan manajerial kepala sekolah didapat nilai rata-rata 4.24 yang berarti sebagian besar responden memberikan jawaban setuju terhadap variabel kemampuan manajerial kepala sekolah.
Responden sebagian besar setuju jika kepala sekolah menyusun rencana kerja sekolah. Diketahui nilai Sig. hasil uji t untuk pengaruh $\mathrm{X}_{1}$ terhadap $\mathrm{Y}$ adalah sebesar $0.000<0.05$ dan nilai $\mathrm{t}_{\text {hitung }} 6.520>\mathrm{t}_{\text {tabel }}$ 1.9727. Hasil koefisien regresi, variabel kemampuan manajerial kepala sekolah (X1) memiliki pengaruh terhadap kinerja guru sebesar 0.222. Hal ini menyatakan bahwa setiap terjadi kenaikan kemampuan managerial kepala sekolah satu satuan akan meningkatkan kinerja guru sebesar 0.222 tanpa dipengaruhi variabel lain. Semakin baik kemampuan managerial kepala sekolah, maka akan meningkatkan kinerja guru di SD Negeri di Kecamatan Tambakromo Kabupaten Pati.

Muslimin dan Rambat (2019) mengatakan bahwa kepala sekolah memiliki peranan yang sangat penting dalam menggerakkan, dan 
menyerasikan semua sumber daya pendidikan yang tersedia di sekolah dan mempergunakan sesuai kebutuhan Artinya, kepemimpinan kepala sekolah merupakan salah satu faktor yang dapat mewujudkan visi, misi, tujuan dan sasaran sekolah melalui program program yang dilaksanakan secara terencana dan bertahap. Kepala sekolah dituntut mempunyai kemampuan manajemen yang memadai agar mampu mengambil inisiatif dan prakarsa untuk meningkatkan mutu pendidikan di sekolah. Hal ini dapat dilakukan salah satunya dengan kemampuan manajerial kepala sekolah dalam hal menyusun rencana kerja sekolah. Karena dengan kemampuan manajerial kepala sekolah yang baik akan meningkatkan kinerja guru.

Penelitian ini mendukung penelitian terdahulu yang dilakukan oleh Amanda dan Yoyon (2018) dan Bandi dan Supriyoko (2019) yang menyatakan bahwa terdapat hubungan yang signifikan antara kemampuan manajerial dengan kinerja guru.

\section{Pengaruh Disiplin Kerja terhadap Kinerja Guru}

Hasil penelitian menunjukkan bahwa disiplin kerja berpengaruh signifikan terhadap kinerja guru SD Negeri di Kecamatan Tambakromo Kabupaten Pati. Hasil tanggapan responden terhadap variabel disiplin kerja didapat nilai rata-rata 4.31 yang berarti sebagian besar responden memberikan jawaban setuju terhadap variabel disiplin kerja. Responden sebagian besar setuju jika mematuhi jam kerja. Diketahui nilai Sig. hasil uji $\mathrm{t}$ untuk pengaruh $\mathrm{X}_{2}$ terhadap $\mathrm{Y}$ adalah sebesar $0.000<0.05$ dan nilai thitung $7.206>$ $t_{\text {tabel }}$ 1.9727. Hasil koefisien regresi, variabel disiplin kerja (X2) memiliki pengaruh terhadap kinerja guru sebesar 0.397. hal ini menyatakan bahwa setiap terjadi kenaikan disiplin kerja satu satuan akan meningkatkan kinerja guru sebesar 0,397 tanpa dipengaruhi variabel lain. Semakin baik disiplin kerja, maka akan meningkatkan kinerja guru SD Negeri di Kecamatan Tambakromo Kabupaten Pati.

Sya'roni, dkk (2018) membuktikan bahwa semakin tinggi kedisiplinan seorang guru maka akan meningkatkan kinerja guru. Guru merupakan panutan bagi siswa-siswanya, sehingga sudah sepatutnya guru memiliki kedisiplinan yang tinggi. Bukan hanya siswa, guru juga mengikuti dan menerapkan semua peraturan yang telah ditetapkan oleh sekolah. Kedisiplinan tersebut dibuktikan dengan beberapa hal, salah satunya adalah ketepatan waktu dalam melaksanakan pekerjaan. Sehingga tidak heran jika guru selalu datang ke sekolah tepat waktu dan mengajar sesuai jadwal mengajar yang diberikan oleh pihak sekolah. Ketepatan waktu tersebut membuat kinerja guru semakin baik.

Penelitian ini mendukung penelitian terdahulu yang dilakukan oleh Ekowati (2018) dan Setiawan dan Basuki (2019) yang menyatakan bahwa terdapat hubungan yang positif dan signifikan antara disiplin kerja dengan kinerja guru.

\section{Pengaruh Kemampuan Manajerial Kepala Sekolah dan Disiplin Kerja terhadap Kinerja Guru}

Hasil penelitian menunjukkan bahwa kemampuan manajerial kepala sekolah dan disiplin kerja berpengaruh secara simultan terhadap kinerja guru. Diketahui nilai Sig. untuk pengaruh kemampuan manajerial kepala sekolah $\left(\mathrm{X}_{1}\right)$ dan disiplin kerja $\left(\mathrm{X}_{2}\right)$ terhadap kinerja guru $(\mathrm{Y})$ adalah sebesar $0.000<0.05$ dan nilai $\mathrm{f}_{\text {hitung }} 229.714>\mathrm{f}_{\text {tabel }}$ 3.04, sehingga dapat disimpulkan bahwa kemampuan manajerial kepala sekolah $\left(\mathrm{X}_{1}\right)$ dan disiplin kerja $\left(\mathrm{X}_{2}\right)$ terdapat pengaruh secara simultan terhadap kinerja guru (Y). Berdasarkan output nilai determinasi diketahui nilai $\mathrm{R}$ Square sebesar 0.71, hal ini mengandung arti bahwa variabel kemampuan manajerial kepala sekolah $\left(\mathrm{X}_{1}\right)$ dan disiplin kerja $\left(\mathrm{X}_{2}\right)$ berpengaruh secara simultan terhadap variabel kinerja guru $(\mathrm{Y})$ sebesar $71 \%$.

\section{SIMPULAN DAN REKOMENDASI}

Berdasarkan hasil penelitian dan atas dasar pengujian hipotesis, secara keseluruhan penulisan tesis dapat diambil kesimpulan sebagai berikut.

1. Kemampuan manajerial kepala sekolah terbukti memiliki pengaruh signifikan terhadap kinerja guru SD Negeri di Kecamatan Tambakromo Kabupaten Pati. 
Hasil uji $\mathrm{t}$ menunjukkan nilai sig. sebesar $0.000<0.05$ dan nilai $t_{\text {hitung }} 6.520>\mathrm{t}_{\text {tabel }}$ 1.9727.

2. Disiplin kerja terbukti memiliki pengaruh signifikan terhadap kinerja guru SD Negeri di Kecamatan Tambakromo Kabupaten Pati. Hasil uji t menunjukkan nilai sig. sebesar $0.000<0.05$ dan nilai $\mathrm{t}_{\text {hitung }} 7.206>\mathrm{t}_{\text {tabel }}$ 1.9727 .

3. Kemampuan manajerial kepala sekolah dan disiplin kerja secara simultan terbukti memiliki pengaruh signifikan terhadap kinerja guru SD Negeri di Kecamatan Tambakromo Kabupaten Pati. Hasil uji Ft menunjukkan nilai sig. sebesar $0.000<0.05$ dan nilai $\mathrm{f}_{\text {hitung }}$ $229.714>f_{\text {tabel }} 3.04$ dan berpengaruh secara simultan terhadap variabel kinerja guru (Y) sebesar $71 \%$.

Berdasarkan pada hasil penelitian dan hasil pengujian hipotesis, penulis memberikan saransaran sebagai berikut.

1. Hasil penelitian ini dapat memberikan masukan bagi kepala sekolah untuk lebih meningkatkan kemampuan manajerial kepala sekolah dan disiplin kerja guru karena sangat berpengaruh terhadap kinerja guru sehingga sekolah dapat mencapai tujuan yang telah ditetapkan.

2. Hasil penelitian ini diharapkan guru lebih semangat dan mempunyai disiplin kerja yang tinggi dalam menjalankan tugasnya sebagai tenaga pendidik yang profesional.

\section{DAFTAR PUSTAKA}

Amanda , R. S., dan Suryono, Y. (2018). Hubungan Kemampuan Manajerial Kepala Satuan Paud dan Self-Efficacy Guru dengan Kinerja Guru di Kecamatan Bukit Kerman Kabupaten Kerinci Propinsi Jambi. Jurnal Akuntabilitas Manajemen Pendidikan, 6(2), 204 - 214.

Bandi dan Supriyoko. (2019). Kontribusi Kemampuan Manajerial Kepala Sekolah, Pengalaman Mengajar Guru, dan Pemanfaatan Fasilitas Belajar terhadap Kinerja Guru. Media Managemen Pendidikan, 2(6), 42 - 51

Damayanti, D. (2017). Kemampuan Manajerial
Kepala Sekolah, Iklim Sekolah dan Mutu Sekolah Dasar. Jurnal Administrasi Pendidikan, 24(1), 154 - 162.

Depdiknas. (2005). Undang-Undang Nomor 14 Tahun 2005, Tentang Guru dan Dosen. Jakarta: Depdiknas.

Depdiknas. (2007). No 13 Tahun 2007 Tentang Standar Kepala Sekolah/Madrasah. Jakarta: Depdiknas.

Depdiknas. (2010). Nomor 28 Tahun 2010 tentang Penugasan Guru sebagai Kepala Sekolah/Madrasah. Jakarta: Depdiknas.

Ekowati, W., Prasetyo, I., dan Chamariyah. (2018). Pengaruh Disiplin Kerja dan Gaya Kepemimpinan Kepala Sekolah Melalui Motivasi Kerja terhadap Kinerja Guru SMPN 1 Penajam Paser Utara. MAP (Jurnal Manajemen dan Administrasi Publik). 1(1), 70-83.

Gita, N., Kustiani, L., dan Firdaus, R. M. (2018). Pengaruh Kemampuan Manajerial Kepala Sekolah, Disiplin Kerja, dan Komunikasi Interpersonal terhadap Kinerja Guru. Jurnal Riset Pendidikan Ekonomi (JRPE), 3(2), 12-20.

Ghozali, I. (2016). Aplikasi Analisis Multivariate Dengan Program SPSS. Semarang: Badan Penerbit Universitas Diponegoro.

Hadis, A., dan Nurhayati, B. (2010). Manajemen Mutu pendidikan. Bandung: Alfabeta.

Lie, D., Sherly, E. D., dan Sudirman, A. (2019). The Impact of Work Discipline and Work Ethic on the Teacher Performance of Sultan Agung Pematangsianta Private Middle School Teachers T.A. 2018/2019. IPMI International Journal Of Business Studies. 3(3), 12-20.

Mangkunegara, A.P. (2012). Evaluasi Kinerja SDM. Bandung: Refika Aditama.

Martono, N. (2014). Metode Penelitian Kuantitatif. Jakarta: PT Raja Grafindo Persada

Moenir, H. A. S. (2012). Manajemen Pelayanan Umum di Indonesia. Jakarta: Bumi Aksara.

Muslimin, A., dan Nursasongko, R. (2019). Pengaruh Gaya Kepemimpinan dan Kemampuan Manajerial Kepala Sekolah Dasar terhadap Kinerja Guru. Manajer 
Pendidikan, 13(2), 127-132

Nitisemito, A. (2014). Manajemen Sumber Daya Manusia. Yogyakarta: BPFE UGM.

Nugraheni, A. S., dan Rahmayanti, R. (2016). Pengaruh Disiplin Kerja Terhadap Kinerja Guru di MI Al Islam Tempel dan MI Al Ihsan Medari. Jurnal Pendidikan Madrasah, 1(2), 12-20.

PP Republik Indonesia. (2010). No 53 tahun 2010 tentang Disiplin Pegawai Negeri Sipil. Jakarta

PP Republik Indonesia. (2019). No 30 tahun 2019 tentang Penilaian Kinerja Pegawai Negeri Sipil. Jakarta

Pratama, M. (2014). Pengaruh Kepemimpinan, Motivasi Kerja dan Disiplin Kerja Terhadap Kinerja Pegawai Balai Wilayah Sungai Sumatra V. Padang: Jurnal UNITAS

Rivai, V. (2011). Manajemen Sumber Daya Manusia untuk Perusahaan: dari Teori ke Praktik. Raja Grafindo Persada, Jakarta.

Sampurno, D., dan Wibowo, A. (2015). Kepemimpinan Kepala Sekolah, Lingkungan Kerja, Motivasi Kerja, Dan Kinerja Guru Di SMK Negeri 4 Pandeglang. Jurnal Pendidikan Ekonomi Dan Bisnis (JPEB), 3(2), 63 - 76.

Sofyan, A. (2012). Manajemen Pemasaran (dalam konsep dan strategi). Jakarta: Rajawali Grafindo.

Stavrinoudis, T., dan Kakarougkas, C. (2017). Faktors of Human Motivation in Organizations: A First Scientific Modeling for a More Effective Application in the Hospitality Industry. International Journal of Cultural and Digital Tourism, 4 (2), 20-30.

Sugiyono. (2011). Metode Penelitian Kuamtitatis, Kualitatif dan $R \& D$. Bandung: Alfabeta

Suherman, A., \& Saondi, O. (2010). Etika Profesi Keguruan. Bandung: PT. Refika Aditama.

Supardi. (2014). Kinerja guru. Jakarta: PT Raja Grafindo Persada.

Susanto, A. (2016). Manajemen Peningkatan Kinerja Guru Konsep, Strategi, dan
Implementasi. Jakarta: Kencana

Sya'roni, T. H., danm Cahyono, D. (2018). Dampak Motivasi, Disiplin Kerja dan Kepemimpinan Kepala Sekolah terhadap Kinerja Guru. JSMBI ( Jurnal Sains Manajemen dan Bisnis Indonesia ), 8(2), $131-147$.

Uno, H.B., \& Lamatenggo, N. (2014). Teori kinerja dan pengukurannya. Jakarta: Bumi Aksara.

Wibowo. (2011). Manajemen Kinerja. Edisi Ketiga. Jakarta: Rajawali Pers 